\title{
MODEL PEMBELAJARAN GENERATIF DALAM UPAYA MENINGKATKAN HASIL BELAJAR MATEMATIKA
}

\author{
Oleh : Sukanto Sukandar Madio
}

Abstract:

The aim of this research is to analyze, (a) mathematical achievement capability of student after learning by Generative model, (b) mastery learning of student after learning by Generative model, and (c) student activities while learning Generative models. This research is directed to class action research in one of public high school in Garut as population subject are all eleventh grade student by taking one class of 41 sttudents as a sample. The result of research shows, (a) mathematical achievement capability of student after learning by Generative model have been changed (increased) in score that received by student, of cycle I to cycle II, of cycle II to cycle III, and of cycle III to cycle IV, (b) mastery learning of student after learning by Generative models not reached yet on cycle I, but reached on cycle II, cycle III, and cycle IV, (c) Learning Condition of implementation of Generative Model have been increased to be better and student learning activity have been increased to be better too.

\section{Pendahuluan}

Dalam kehidupan kita seringkali dihadapkan dengan berbagai masalah yang harus dicarikan pemecahannya. Untuk dapat memecahkan masalah tersebut diperlukan kualitas sumber daya manusia yang baik. Dalam hal ini Sukasno (2002) mengemukakan pendidikan matematika mempunyai potensi besar untuk memainkan peran strategis dalam menyiapkan sumber daya manusia untuk menghadapi era industrialisasi dan globalisasi. Potensi ini dapat terwujud jika pendidikan matematika mampu melahirkan peserta didik yang cakap dalam matematika dan berhasil menumbuhkan kemampuan berpikir logis, bersifat kritis, kreatif, inisiatif, dan adaptif terhadap perubahan dan perkembangan . Kualitas sumber daya manusia seperti ini menjamin keberhasilan upaya penguasaan teknologi untuk pembangunan di Indonesia.

Matematika merupakan salah satu disiplin ilmu yang memiliki peranan penting dalam pengembangan ilmu pengetahuan dan teknologi, sehingga matematika perlu dipahami dengan baik oleh seluruh lapisan masyarakat, terutama oleh siswa, mahasiswa dan ilmuwan lainnya. Dalam hal ini Ruseffendi (1991:94) menyatakan bahwa "matematika dapat menjadi pembimbing pola pikir maupun sebagai pembentuk sikap".

\begin{tabular}{lrr}
\multicolumn{1}{c}{ Pusat } & \multicolumn{1}{c}{ kurikulum, } & Balitbang \\
Depdiknas & (Depdiknas, & $2003: 3$ ) \\
menyatakan & bahwa mata & pelajaran \\
matematika & menumbuhkembangkan \\
kemampuan & menalar, yaitu berpikir
\end{tabular}
sistematis, logis, dan kritis, dalam mengkomunikasikan gagasan atau dalam pemecahan masalah. Oleh karena itu berdasarkan Pugalee (2001), siswa perlu dibiasakan dalam pembelajaran untuk memberikan argumen setiap jawabannya serta memberikan tanggapan atas jawaban yang diberikan oleh orang lain, sehingga apa yang sedang dipelajari menjadi bermakna baginya.

Sudah menjadi gejala umum bahwa mata pelajaran matematika kurang disukai oleh kebayakan siswa. Menurut Wahyudin (1999:253), matematika merupakan mata pelajaran yang sukar dipahami, sehingga kurang diminati oleh sebagian siswa. Ketidaksenangan terhadap mata pelajaran matematika ini dapat berpengaruh terhadap keberhasilan belajar matematika siswa. Dengan demikian perbaikan penyelenggaraan 
proses pembelajaran matematika menjadi hal yang menarik untuk disiasati. Sumarmo (2000:1) mengemukakan bahwa proses pembelajaran matematika sebaiknya memenuhi keempat pilar pendidikan masa datang dari UNESCO.

Mengacu pada kemampuan siswa yang diharapkan pada keempat pilar UNESCO dan salah satu tujuan umum pembelajaran matematika, mengembangkan daya matematik (mathematical power) siswa, model pembelajaran Generatif adalah salah satu pendekatan pembelajaran yang memberi peluang untuk berkembangnya daya matematik melalui keleluasaaan berfikir siswa secara aktif dan kreatif dalam menyelesaikan suatu permasalahan. Hal ini dimungkinkan karena model pembelajaran Generatif disajikan dengan langkah-langkah yang sitematis. Langkah-langkah model pembelajaran generatif yang diusulkan oleh Osborne dan Wittrock (1985) terdiri dari lima tahapan yaitu tahap orientasi, tahap pengungkapan ide, tahap tantangan dan restrukturisasi, tahap penerapan, dan tahap melihat kembali pembelajaran yang telah dilaksanakan.

Tahap pertama adalah tahap orientasi, yaitu untuk memotivasi siswa untuk mempelajari materi yang diberikan. Pada tahap ini siswa diberi kesempatan untuk membangun kesan mengenai topik yang akan dibahas dengan mengaitkan materi dengan pengalaman mereka sehari-hari. Tujuannya agar siswa termotivasi mempelajari pokok bahasan tersebut. Tahap kedua adalah tahap pengungkapan ide, yaitu untuk mengungkap konsepsi awal siswa yang beragam tentang topik yang akan dibahas. Pada tahap ini siswa diberi kesempatan untuk mengemukakan ide mereka dengan berdiskusi dan mengerjakan LKS, sedangkan guru menampung pendapat siswa dengan menyalahkan atau membenarkan, hanya berusaha menciptakan suasana untuk menyadarkan siswa bahwa terdapat pendapat yang berbeda dengan teman-temannya. Tahap ketiga adalah tahap tantangan dan restrukturisasi, yaitu untuk menciptakan terjadinya konflik pada siswa. pada tahap ini siswa diharapkan tampil didepan kelas untuk mempresentasikan jawaban LKS dan guru menyiapkan suasana dimana siswa diminta membandingkan pendapatnya dengan pendapat siswa lain dan mengemukakan keunggulan dari pendapat mereka. Tahap keempat adalah tahap penerapan, yaitu untuk memberikan kesempatan kepada siswa menerapkan konsepsinya dalam menyelesaikan persoalan yang bervariasi. Tahap kelima adalah tahap melihat kembali apa saja yang mereka pelajari selama pembelajaran.

\section{Temuan Penelitian}

Penelitian ini bertujuan menelaah mengenai: (a) peningkatan kemampuan matematika siswa yang belajar dengan model pembelajaran Generatif dari setiap siklusnya; (b) ketuntasan belajar matematika dari setiap siklusnya; dan (c) suasana dan aktivitas belajar siswa selama pembelajaran Generatif.

\section{Metodologi}

Dalam penelitian ini penulis memilih metode penelitian tindakan kelas (PTK) yang dilaksanakan secara kolaboratif dengan guru yang kelasnya dijadikan tempat penelitian. Pelaksanaan penelitian ini dilakukan dalam 4 (empat) siklus, hal ini dilakukan karena dengan 4(empat) siklus sudah dicapai ketuntasan hasil belajar dan kecenderungan peningkatan kemampuan matematika, ketuntasan, dan ativitas siswa.

Langkah kerja penelitian ditempuh mencakup: (1) menyiapkan rancangan pembelajaran dan instrumen penelitian; (2) menganalisis hasil uji coba instrumen penelitian; (3) melaksanakan pembelajaran dengan model pembelajaran Generatif, dalam upaya mengkatkan kemampuan matematika siswa. Materi yang dipilih pada penelitian ini adalah turunan fungsi aljabar. Pelaksanaan pembelajaran dilaksanakan oleh guru mata pelajaran di kelas yang digunakan untuk melaksanakan 
yang mencapai nilai $\geq 6,5(65 \%)$ atau sebesar $82,93 \%$, pada siklus III terdapat 37 siswa dari 41 siswa yang mencapai nilai $\geq 6,5(65 \%)$ atau sebesar 90,24 \%, sedangkan pada siklus IV terdapat 37 siswa dari 41 siswa yang mencapai nilai $\geq 6,5(65 \%)$ atau sebesar $90,24 \%$.

Begitu pula ketuntasan belajar siswa pun meningkat. Pada siklus I hasil belajar siswa belum mencapai ketuntasan, tetapi pada siklus II, siklus III dan siklus IV hasil belajar siswa tuntas. Hal ini dimungkinkan karena pada siklus I siswa masih beradaptasi dengan model pembelajaran yang baru.

Rata-rata tes hasil belajar siswa meningkat dari siklus I ke siklus II, siklus II ke siklus III, dan dari siklus III ke siklus IV. Tetapi peningkatan hasil belajar hanya meningkat dari siklus I ke siklus II saja. Penurunan kemampuan pada siklus selanjutnya tidak terlalu signifikan karena rerata nilainya meningkat. Hal ini dapat dijelaskan sebagai berikut: (a) siklus-siklus II, III, dan IV soal-soal tes semakin kompleks ; (b) dilihat dari standar deviasinya bahwa kemampuan siswa semakin menyebar ; (c) dilihat dari reratanya yang meningkat artinya kemampuannya semakin tinggi; dan (d) semakin banyak siswa yang tuntas belajarnya.

\section{Suasana Pembelajaran Model Pembelajaran Generatif}

Suasana pembelajaran dengan model pembelajaran Generatif, dengan menggunakan skala Guttman gambarannya dapat dilihat pada tabel 3 berikut ini.

Tabel 3. Suasana Pembelajaran Selama Model Pembelajar an Generatif

\begin{tabular}{|c|c|c|c|c|c|}
\hline \multirow[t]{2}{*}{ No } & \multicolumn{2}{|l|}{ Uraian } & \multicolumn{2}{|c|}{ Pertemuan } & \multirow[b]{2}{*}{ IV } \\
\hline & & I & & & \\
\hline 1 & Situas kelas mendukurg untuk dilakukan PBM & $\checkmark$ & $\sqrt{ }$ & $\sqrt{ }$ & $\sqrt{ }$ \\
\hline 2 & Siswa kttf meng emukakan pend ạ d & - & $\sqrt{ }$ & $\sqrt{1}$ & \\
\hline 3 & Siswa ktif menghomurikaskan pendap at & . & . & $\sqrt{ }$ & \\
\hline 4 & Adanya tanyajawah antara siswa dengan guru & $\sqrt{ }$ & $\sqrt{ }$ & $\sqrt{ }$ & $\sqrt{ }$ \\
\hline 5 & Adanya tanya jawab antera siswa dengan siswa & 1 & $\sqrt{ }$ & 1 & $\sqrt{1}$ \\
\hline 6 & Terjadi kegaduhan dikelas & T & - & $\cdot$ & \\
\hline 7 & Penbicaran hanga didomin asi gurn & & . & . & \\
\hline 8 & Penah terjadi ketegangan ant ara guru dengan \&s swa & - & - & $\cdot$ & \\
\hline 9 & Selama PBM ada siswa gang minta jin keluar & - & - & - & $\sqrt{ }$ \\
\hline 10 & $\begin{array}{l}\text { Tampals suasana kelas merjadikan siswa enggan } \\
\text { bettanya }\end{array}$ & & & & - \\
\hline
\end{tabular}

Berdasarkan hasil observasi terhadap suasana pembelajaran menunjukkan bahwa pada siklus tindakan pembelajaran I motivasi siswa rendah, aktivitas siswa tidak begitu antusias dan bahkan pernah tejadi kegaduhan didalam kelas yang tidak relevan dengan KBM. Namun pada siklus tindakan II-IV keadaan tersebut mulai berkurang dan akhirnya terciptalah suasana pembelajaran yang kondusif. Siswa aktif mengemukakan pendapatnya, motivasi siswa untuk belajar matematika tinggi, suasana kelas menyenangkan, terjadinya diskusi antar siswa.

\section{Aktivitas Belajar Siswa selama Pembelajaran}

Berdasarkan hasil observasi aktivitas belajar siswa tergambar pada tabel 4 berikut ini.

Tabel 4. Persentase Aktifitas Belajar Siswa

\begin{tabular}{|c|c|c|c|c|c|}
\hline & \multirow{2}{*}{ Kegiatan Yang Dismati } & \multicolumn{4}{|c|}{ Perseutase tiap pratemaan $(5 s)$} \\
\hline No & & I & प & III & IV \\
\hline $\mathbf{1}$ & 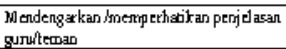 & 58,54 & 75,60 & 81,92 & 87,80 \\
\hline 2 & Mengerjatan LKS & 78,05 & 78,05 & 85,36 & 90,24 \\
\hline j & Berdithusilbertanya antra sispa dsn guru & 4,87 & 9,76 & 7,32 & T,32 \\
\hline 4 & Berch zusublbettamya antra stswa da saswa & 24,39 & 43,90 & 41,46 & 46,34 \\
\hline 3 & Tanpil didep an kelas & 4,87 & $9, T_{3}$ & $1 \mathrm{T,07}$ & 14,63 \\
\hline 6 & Mengenulukat ude'pendap at & 4,87 & 7,32 & 12,19 & 7.32 \\
\hline 7 & Penlaku Yang tid al rederan dongan K.BM & 34,15 & 29,29 & 14,36 & 24,39 \\
\hline
\end{tabular}

Secara umum aktivitas belajar siswa cukup baik. Sebagian besar siswa aktif memperhatikan penjelasan dari guru atau pendapat temannya, begitu pula dalam hal mengerjakan LKS. Dari siklus I sampai dengan siklus IV cenderung terjadi peningkatan. Dalam hal siswa bertanya pada guru frekuensinya kecil dan cenderung menurun, sedangkan diskusi atau tanya jawab antara siswadengan siswa frekuensinya semakin meningkat. Begitu pula siswa yang tampil di depan kelas dan yang mengemukakan ide atau pendapat semakin meningkat. Sedangkan perilaku siswa yang tidak relevan dengan KBM semakin menurun.

\section{Kesimpulan}

1. Kemampuan Matematika siswa setelah penbelajaran dengan menggunakan model pembelajaran Generatif mengalami peningkatan. 
2. Secara umum suasana pembelajaran dengan model pembelajaran Generatif sangat kondusif, dan cenderung semakin membaik.

3. Aktivitas siswa setelah pembelajaran dengan model pembelajaran Generatif semakin meningkat sedangkan peranan guru semakin berkuran. Senagian besar siswa antusias dalam proses pembelajaran.

\section{Daftar Rujukan}

Depdiknas. (2003). Kurikulum Berbasis Kompetensi. Jakarta: Pusat Kurikulum, Balitbang Depdiknas.

Indrawati. (1999). Model-model Pembelajaran IPA. Bandung: Pusat Pengembangan Penataran Guru IPA

Joiced, Bruce \& Weil, Marsha \& Calhoum, With Emily. (2000). Model of Teaching. Sixth Edition. Boston: Allyn and Bacon.

Mulyasa, E. (2003). Kurikulum Berbasis Kompetensi Konsep, Karakteristik, dan Implementasi. Bandung: P.T. Remaja Kara

Osborne, R.I. \&Wttrock,M.C. (1985). The Generative Learning Models and Implicatin for Science Education, Studies in Science Edication Vol. 12. Los Angeles: Department of Education, University of California

Pugalee, D.A. (2001). Using Communication to Develop Students' Mathematical Literacy. JRME. V6 January 2001.

Ruseffendi, E.T. (1991). Pengantar
Membantu
Guru
Mengembangkan
Kompetensinya
Pengajaran
dalan
untuk Meningkatkan CBSA.
Bandung: Tarsito.

PENULIS

Sukanto Sukandar M. Dosen Kopertis Wilayah IV Jawa Barat dan Banten dipekerjakan pada STKIP Garut dan menjabat
Ketua Lembaga Pengendalian Mutu Pendidikan dan Kerjasama STKIP Garut. 
Mosharafa

Jurnal Pendidikan Matematika

Volume 1, Nomor 1, Mei 2012 